\title{
Labile organic carbon regulates phosphorus release from eroded soil transported into anaerobic coastal systems
}

\author{
Jouni Lehtoranta, Petri Ekholm, Stella Wahlström, \\ Petra Tallberg, Risto Uusitalo
}

\begin{abstract}
Coastal eutrophication is expected to increase due to expanding and intensifying agriculture which causes a large amount of soil-associated $\mathrm{P}$ to be transported into aquatic systems. We performed anaerobic long-term incubations on field soil to mimic the conditions that eroded soil encounters in brackish sediments. The release of $\mathrm{P}$ from soil increased with the amount of labile organic $\mathrm{C}$ (acetate) addition and decreased with the soil/solution ratio. We deduce that in less-productive brackish systems, microbial $\mathrm{Fe}$ reduction allows for the maintenance of the coupled cycling of $\mathrm{Fe}$ and $\mathrm{P}$ and restricts the amount of $\mathrm{P}$ entering the oxic water. In more eutrophic systems, the formation of $\mathrm{Fe}$ sulfides as a result of $\mathrm{SO}_{4}$ reduction inactivates $\mathrm{Fe}$, and leads to a higher release of $\mathrm{P}$, thus generating an adverse feedback effect. The dependence of the fate of soil-bound Fe and $\mathrm{P}$ on the trophic status of the receiving water should be recognized in eutrophication management.
\end{abstract}

Keywords Coastal waters - Agriculture - Sediment . Eutrophication $\cdot$ Fe oxides $\cdot$ Redox reactions

\section{INTRODUCTION}

Agricultural phosphorus (P) losses cause eutrophication and hypoxia in coastal waters (Conley et al. 2011). Eutrophication abatement policies tend to rely on total $\mathrm{P}$ as the indicator for $\mathrm{P}$ loading, and thus give an equal weighting to all $\mathrm{P}$ forms, independent of their physical form and bioavailability (see Jansson et al. 2012). Phosphorus is transported from arable land to waters in two major forms: (1) dissolved, readily bioavailable $\mathrm{P}$ and (2) soil-bound $\mathrm{P}$ that has to be released into a dissolved form before incorporation by biota. Soil-bound $\mathrm{P}$ dominates especially in runoff from fine grained soils lacking perennial vegetation (Rekolainen et al. 2006; Ulén et al. 2010).

Erosion control is a widely used P-reduction measure, but it is not clear whether it reduces the losses of bioavailable P. First, tillage practices that aim to prevent soil loss may increase the losses of dissolved P (Uusitalo et al. 2007; Puustinen et al. 2010; Ulén et al. 2010; Daloğlu et al. 2012). Second, the bioavailability of soil-bound $P$ involves complex biogeochemical processes, the outcome of which may be site specific (Ekholm and Lehtoranta 2012). To design efficient agri-environmental measures, the eutrophying effect of soil-bound $\mathrm{P}$ should be known. This knowledge is particularly important as agricultural production is expected to expand and intensify (Tilman et al. 2002), and the changing climate may further increase erosion (Puustinen et al. 2007).

The bioavailability of soil-bound $\mathrm{P}$ has been estimated by algal assays (DePinto et al. 1981; Ekholm and Krogerus 2003), anion exchange resins (e.g. Uusitalo and Ekholm 2003), and iron (Fe) oxide-impregnated filter papers (Ekholm and Yli-Halla 1992; Sharpley 1993). In general, about $20-30 \%$ of the soil-bound $\mathrm{P}$ in agricultural runoff has been found to be bioavailable using the above methods (DePinto et al. 1981; Rekolainen et al. 2006), which, in effect, estimate the $\mathrm{P}$ that can be desorbed from eroded soil particles on their way from the field, through rivers to lakes and coastal waters. In other words, the methods mimic the effect of the changing soil/solution ratio (Hartikainen et al. 2010). Sooner or later, the soil particles will end up in sediments, where they will encounter anaerobic conditions. Of the anaerobic mineralization processes, sulfate $\left(\mathrm{SO}_{4}\right)$ reduction may result in a massive $\mathrm{P}$ release, because its end-products, sulfides (e.g., $\mathrm{HS}^{-}, \mathrm{H}_{2} \mathrm{~S}$ ), inactivate the major P-sorption component, $\mathrm{Fe}$ oxides (Roden and Edmonds 1997). Extraction with buffered sodium 
dithionite $\left(\mathrm{Na}_{2} \mathrm{~S}_{2} \mathrm{O}_{4}\right)$ has been considered as mimicking the $\mathrm{P}$ release mediated by sulfides, and it has captured as much as $60 \%$ of the total P in Finnish clayey soils (Uusitalo and Turtola 2003). However, it is not known whether dithionite extraction describes the $\mathrm{P}$ release which occurs through anaerobic microbial processes that couple the cycles of carbon (C), Fe, sulfur (S), and P in sediments (Burgin et al. 2011). Using the theoretical basis of coupled biogeochemical cycles, Lehtoranta et al. $(2008,2009)$ have proposed that the release of $\mathrm{P}$ from sediments is related to regional variations in $\mathrm{Fe}$ and $\mathrm{SO}_{4}$ reduction and that this variation stems from the varying supply of organic $\mathrm{C}$.

Here, we hypothesize that the bioavailability of soilbound $\mathrm{P}$ in marine and brackish water is related to the supply of organic C. We carried out anaerobic soil incubations with varying organic $\mathrm{C}$ amendments and soil/ solution ratios to study the behavior of soil-bound $\mathrm{P}$ encountering anoxic brackish conditions. The aim was to use the results for discussion of how the trophic status of the coastal system may control the behavior of soil matter $\mathrm{P}$ settled at the bottom. The study highlights that the extent of sedimentary microbial processes needs to be taken into account when planning water protection measures for the brackish systems such as the Baltic Sea.

\section{MATERIALS AND METHODS}

\section{Soil and its analysis}

The surface $(0-20 \mathrm{~cm})$ soil used in the incubations has been taken from a cultivated field (Tammela, southern Finland, $60^{\circ} 49.228^{\prime} \mathrm{N} ; 23^{\circ} 44.47^{\prime} \mathrm{E}$ ). It is a silty clay by texture and has a moderate $\mathrm{P}$ status according to Finnish and high $\mathrm{P}$ status according to other agronomic indices (Table 1). To determine "pH-sensitive" and "alkali-extractable" pools of $\mathrm{P}$, the soil ( $400 \mathrm{mg}$ ) was extracted with a nutrient medium ( $40 \mathrm{ml}$, see below) adjusted by Tris buffer (see below) at $\mathrm{pH} 9$, and with $0.1 \mathrm{M} \mathrm{NaOH}(40 \mathrm{ml})$. Both extractions were performed repeatedly five times ( $1 \mathrm{~h}$ each) with centrifugation between the extractions and analysis of the supernatant. The soil was also extracted with buffered dithionite according to Uusitalo and Turtola (2003). The method was originally used to characterize $\mathrm{P}$ in runoff that contains eroded soil, and for a higher confidence of the estimate when applied to soil analysis, the extraction was done using a dilution series with soil concentrations of $0.62,0.98,1.50,1.79,2.62$, and $3.00 \mathrm{~g}$ in a liter of deionized water. One milliliter of $0.298 \mathrm{M} \mathrm{NaHCO}_{3}$ (as a pH buffer) and $1 \mathrm{ml}$ of $0.574 \mathrm{M} \mathrm{Na}_{2} \mathrm{~S}_{2} \mathrm{O}_{4}$ (as the reducing agent) were added to $40 \mathrm{ml}$ of soil-water suspension, the samples were immediately capped, shaken for $15 \mathrm{~min}$, filtered $(0.2-\mu \mathrm{m}$ Whatman/Nuclepore polycarbonate filters), and analyzed for total dissolved P (filtered samples digested in an autoclave with peroxodisulfate-sulfuric acid) using a LaChat QuickChem 8000 flow injection analyzer (general detection limit $3 \mu \mathrm{g} \mathrm{L}^{-1}$, and for BD extraction $23 \mu \mathrm{g} \mathrm{L}^{-1}$ ) employing molybdate colorimetry and for dissolved $\mathrm{Fe}$ with an inductively coupled plasma-optical emission spectrometer (ICP-OES, diluted in $1 / 1$ with $6 \mathrm{M}$ $\mathrm{HCl}$ to reduce reprecipitation of $\mathrm{Fe}$ in aerobic environment). The digestion efficiency for BD extraction for $\mathrm{Fe}$ precipitate treated with $\mathrm{P}$ addition was $72 \%$ (Uusitalo and Turtola 2003). A similar extraction by water was also done (soil concentrations $0.60,0.95,1.70,2.18,2.63$, and $3.25 \mathrm{~g}^{-1}$ ). The results reported in this paper refer to the difference between dithionite-extractable $\mathrm{P}$ and waterextractable $\mathrm{P}$ at each soil/solution ratio.

\section{Anaerobic incubations}

To estimate the mutual effects of organic $\mathrm{C}$ and soil/ solution ratio on anaerobic $\mathrm{P}$ release, various amounts of soil were incubated by adding organic $\mathrm{C}$ in the form of acetate as an electron donor. The absence of $\mathrm{O}_{2}$ and $\mathrm{NO}_{3}$ guaranteed that there were only three electron acceptors present: $\mathrm{Fe}$ and $\mathrm{Mn}$ oxides provided by the soil and $\mathrm{SO}_{4}$ by the brackish medium. Note that the experimental setup did not allow for the renewal of the $\mathrm{Fe}$ oxide pool through endogenous oxidation processes by $\mathrm{O}_{2}$ and $\mathrm{NO}_{3}$, i.e., the 'ferrous wheel' was inactivated. The experimental design followed a response surface methodology with a central composite design, i.e., a first-order design augmented by additional center and axial points, with soil and organic $\mathrm{C}$ acting as variables. Five replicates were placed at the central point $(0.25 \mathrm{~g}$ soil, $3 \mathrm{mg} \mathrm{C}$, Fig. 1).

Two incubations were performed. In Incubation 1, airdried soil was weighed (levels: 0.062, 0.088, 0.125, 0.250, $0.500,0.707$, and $1.0 \mathrm{~g}$ ) into $100-\mathrm{ml}$ glass bottles developed for anaerobic incubations. In addition to this, there were three control units containing test solution only. The bottles were filled with $80 \mathrm{ml}$ of filtered water $(0.2 \mu \mathrm{m}$ polypropylene membranes) from the coastal Gulf of Finland (Karpinselkä, Helsinki, about 5 practical salinity units; UNESCO, 1981) containing $310 \mathrm{mg} \mathrm{l}^{-1}$ of $\mathrm{SO}_{4}$. Sodium acetate $\left(\mathrm{CH}_{3} \mathrm{COONa}\right)$ was added at levels: 0 , $0.375,0.75,1.5,3,6,12$, and $24 \mathrm{mg} \mathrm{C}$. The solutions' $\mathrm{pH}$ was buffered to 8.1 by diluting $1.51 \mathrm{~g}$ of the Tris buffer (tris(hydroxymethyle)aminomethane) Sigma Trizma base with $25 \mathrm{ml}$ of distilled water. Each bottle was inoculated with $10 \mu \mathrm{l}$ of surface $(0-1 \mathrm{~cm})$ sediment from the Gulf of Finland (Vanhankaupunginlahti Bay, Helsinki) and bubbled with $\mathrm{N}_{2}$ gas. To simulate the cold sedimentary environment of the Gulf of Finland and the long-term effect of the geochemical processes, the bottles were incubated at 
Table 1 Characteristics of the soil used in the incubations

\begin{tabular}{|c|c|c|c|}
\hline Variable & Extraction & Unit & Value \\
\hline \multirow[t]{9}{*}{ Phosphorus } & $0.5 \mathrm{M}$ ammonium acetate-acetic acid, $\mathrm{pH} 4.65^{\mathrm{a}}$ & $\mathrm{mg}^{-1}$ & 15.0 \\
\hline & Water & $\mathrm{mg} \mathrm{g}^{-1}$ & $0.022-0.030^{\mathrm{e}}$ \\
\hline & Repeated nutrient medium, pH 9 & $\mathrm{mg} \mathrm{g}^{-1}$ & 0.050 \\
\hline & Olsen-P & $\mathrm{mg} \mathrm{kg}^{-1}$ & 69.0 \\
\hline & Mehlich-3 P & $\operatorname{mg~} 1^{-1}$ & 95.0 \\
\hline & Anion exchange resin ${ }^{\mathrm{b}}$ & $\mathrm{mg} \mathrm{g}^{-1}$ & 0.12 \\
\hline & Buffered dithionite & $\mathrm{mg} \mathrm{g}^{-1}$ & $0.13-0.21^{\mathrm{e}}$ \\
\hline & Repeated $0.1 \mathrm{M} \mathrm{NaOH}$ & $\mathrm{mg} \mathrm{g}^{-1}$ & 0.57 \\
\hline & Total $^{\mathrm{c}}$ & $\mathrm{mg} \mathrm{g}^{-1}$ & 1.47 \\
\hline \multirow[t]{2}{*}{ Iron } & Buffered dithionite & $\mathrm{mg} \mathrm{g}^{-1}$ & 1.7 \\
\hline & Oxalate $^{\mathrm{d}}$ & $\mathrm{mg} \mathrm{g}^{-1}$ & 9.7 \\
\hline Aluminum & Oxalate & $\mathrm{mg} \mathrm{g}^{-1}$ & 2.5 \\
\hline $\mathrm{Ca}$ & $0.5 \mathrm{M}$ ammonium acetate-acetic acid, $\mathrm{pH} 4.65^{1}$ & $\operatorname{mg~} 1^{-1}$ & 3030 \\
\hline $\mathrm{K}$ & $0.5 \mathrm{M}$ ammonium acetate-acetic acid, $\mathrm{pH} 4.65^{1}$ & $\operatorname{mg~} 1^{-1}$ & 370 \\
\hline $\mathrm{Mg}$ & $0.5 \mathrm{M}$ ammonium acetate-acetic acid, $\mathrm{pH} 4.65^{1}$ & $\mathrm{mg} 1^{-1}$ & 1060 \\
\hline $\mathrm{C}$ & & $\% \mathrm{DW}$ & 2.3 \\
\hline $\mathrm{N}$ & & $\% \mathrm{DW}$ & 0.19 \\
\hline $\mathrm{pH}$ & & & 6.6 \\
\hline
\end{tabular}

${ }^{a}$ Finnish soil test analysis (Vuorinen and Mäkitie 1955)

b Analysis based on Sibbesen (1977)

c Analysis based on Bowman (1988)

d Analysis based on Schwertmann (1964) using ICP-OES

e Minimum and maximum of the extractions with six soil/solution ratios

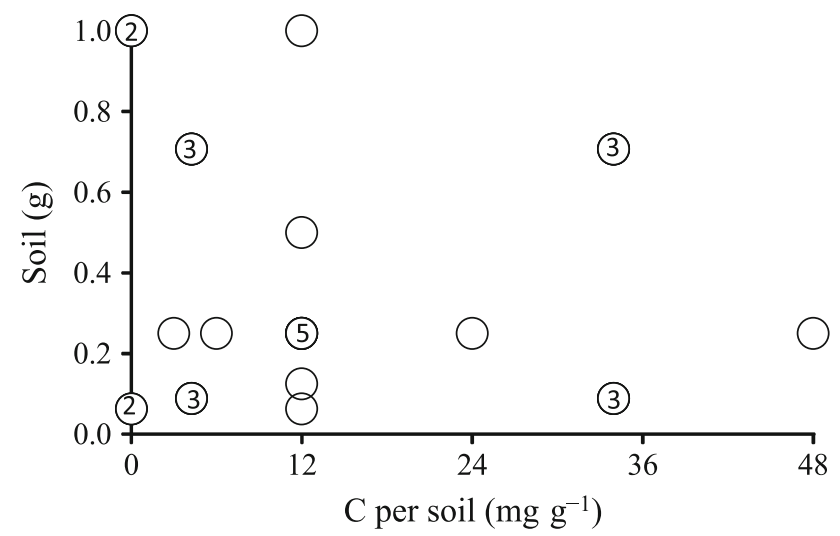

Fig. 1 Experimental design following a response surface methodology. The circles denote the experimental units, and the numbers inside the circles refer to replicates ranging from 2 to 5 . The number is missing when there were no replicates; in Incubation 2, two replicates were used instead of three

$5^{\circ} \mathrm{C}$ close to temperature of bottom waters in the dark for 861 days. This was anticipated as enough time to demonstrate the outcome of the long-term geochemical processes on $\mathrm{P}$ release from soil settled in an anoxic environment. On days 738 and 861, the solution concentrations of $\mathrm{Al}, \mathrm{Ca}$, $\mathrm{Fe}, \mathrm{K}, \mathrm{Mg}, \mathrm{Mn}, \mathrm{Na}, \mathrm{P}$, and $\mathrm{S}$ were measured using ICP-
OES (Thermo iCAP6000) after filtration (WWR International 25-mm Syringe Filter, polypropylene membrane with $0.2-\mu \mathrm{m}$ pore size). $\mathrm{SO}_{4}$ was determined by ion chromatography, $\mathrm{H}_{2} \mathrm{~S}$ colorimetrically with a prepared cuvette test (Hach Lange LCK 653), and pH potentiometrically.

Incubation 2 was similar to Incubation 1, apart from the test solution, the duration, and the temperature of the experiment. Moreover, $\mathrm{C}$ was added also during the incubation (on days 141 and 196) to establish the effect of labile $\mathrm{C}$ on a stabilized system. The test solution consisted of a P-free nutrient medium $5 \%$ Z8 (Kotai 1972) with a salt component (about 6 practical salinity units, Ekholm et al. 2009). To study the effect of a higher $\mathrm{SO}_{4}$ concentration, $\mathrm{K}_{2} \mathrm{SO}_{4}$ was added to give an initial concentration of $2.4 \mathrm{~g}^{-1} \mathrm{SO}_{4}$, corresponding to that of sea. Moreover, $\mathrm{NH}_{4}$ was added to ensure sufficient $\mathrm{N}$ for bacterial activity to yield a concentration of $2 \mathrm{mg} \mathrm{l}^{-1} \mathrm{~N}$, a level found in pore waters of the sediments in the Gulf of Finland (Lehtoranta and Pitkänen 2003). The incubation took place on a shaking table at $10^{\circ} \mathrm{C}$ in the dark for 308 days. At the end of the incubation, $\mathrm{pH}$, dissolved reactive $\mathrm{P}$ (molybdate blue colorimetry), and dissolved $\mathrm{Fe}$ were analyzed. 


\section{Statistical analysis}

A multivariate regression analysis was performed using SAS for Windows (9.3) to investigate the dependences of $\mathrm{P}$ release $\left(P, \mathrm{mg} \mathrm{g}^{-1}\right)$ on soil (soil, $\left.\mathrm{g}\right)$ and $\mathrm{C}(C, \mathrm{mg}$, Eq. 1$)$. The regression model included two terms. The first term was assumed to account for $\mathrm{P}$ desorption and was an inverse exponential function of soil, i.e. the more soil there was in a unit, the lower the amount of $\mathrm{P}$ released per gram of soil. The form followed the experimental results of e.g., Yli-Halla and Hartikainen (1996) and Yli-Halla et al. (1995). The second term was assumed to represent the effect of Fe reduction (either microbiological or mediated by $\mathrm{H}_{2} \mathrm{~S}$ ) on the $\mathrm{P}$ release. Here, the mineralization of organic $\mathrm{C}$ was assumed to follow first-order reaction kinetics. The assumption was justified by the use of a single and readily available $\mathrm{C}$ source (acetate), although the organic matter in soil, exhibiting a more complex degradation (Vähätalo et al. 2010), may also have been mineralized in the experiment.

$P=P_{\text {soilmax }} \cdot e^{-k_{1} \cdot \text { soil }}+P_{C \max } \cdot\left(1-e^{-k_{2} \cdot C}\right)$.

The coefficients $P_{\text {soilmax }}, P_{C \max }, k_{1}$ and $k_{2}$ were numerically approximated with PROC NLIN in SAS. The model's goodness of fit was evaluated with the NashSutcliffe efficiency index $E_{\mathrm{f}}$ (Nash and Sutcliffe 1970):

$E_{\mathrm{f}}=1-\frac{\sum_{i=1}^{n}\left(\widehat{Y}_{i}-Y_{i}\right)^{2}}{\sum_{i=1}^{n}\left(Y_{i}-\bar{Y}\right)^{2}}$,

where $\widehat{Y}_{i}$ is the modeled value, and $Y_{i}$ is the observed value, $\bar{Y}$ is the average of the observed values, and $n$ is the number of observations. The index ranges from $-\infty$ to 1 , with a value of 0 indicating that the predictions are as accurate as the mean of the observations and a value of 1 indicating a perfect match.

\section{RESULTS}

\section{Soil $P$ and $F e$}

The $\mathrm{P}$ extracted by buffered dithionite ranged from 0.13 to $0.21 \mathrm{mg} \mathrm{g}^{-1}$ (Table 1), and the extracted $\mathrm{P}$ increased with the decreasing soil/solution ratio of the extraction (data not shown). The upper boundary accounted for $17 \%$ of the total $\mathrm{P}$ in soil and was about twice the concentrations of anion exchange resin-extractable $\mathrm{P}$ and Mechlich-3 $\mathrm{P}$ and tenfold the concentration of water-extractable $\mathrm{P}$ (Table 1). A higher amount of $\mathrm{P}$ was removed by the repeated $\mathrm{NaOH}$ extraction $\left(0.57 \mathrm{mg} \mathrm{g}^{-1}\right)$, while the repeated extraction by nutrient medium at $\mathrm{pH} 9$ gave only $0.05 \mathrm{mg} \mathrm{g}^{-1}$ of $\mathrm{P}$. Of the soil $\mathrm{Fe}, 1.7$ and $9.7 \mathrm{mg} \mathrm{g}^{-1}$, were extracted by dithionite and oxalate, respectively (Table 1). Of the oxalate-extractable metals, the mass of $\mathrm{Fe}$ was about four times that of aluminum ( $\mathrm{Al}$ ), the molar ratio being about two $\left(175 \mathrm{mmol} \mathrm{kg}^{-1} \mathrm{Fe}\right.$ vs. $\left.95 \mathrm{mmol} \mathrm{kg}^{-1} \mathrm{Al}\right)$.

\section{Mineralization processes}

Indices of anaerobic mineralization processes were detected in all the experimental units. Even in the units without acetate addition, $\mathrm{Mn}$ and $\mathrm{Fe}$ accumulated in the solution, suggesting that the organic $\mathrm{C}$ present in the soil was able to launch $\mathrm{Mn}$ and $\mathrm{Fe}$ reduction (brown circles in Fig. 2a, b). Dissolved Fe was only detected in the units with $\mathrm{C} /$ soil ratios $\left(\mathrm{mg} \mathrm{g}^{-1}\right)$ of less than 6 (brown and gray circles in Fig. 2b). Higher $\mathrm{C} /$ soil ratios (black marks in Fig. 2) appeared to enable $\mathrm{SO}_{4}$ reduction, as suggested by a strong decrease in $\mathrm{SO}_{4}$ concentration, accumulation of $\mathrm{H}_{2} \mathrm{~S}$ (Fig. 2c), and smell. The end-products of $\mathrm{Fe}$ and $\mathrm{SO}_{4}$ reduction, dissolved $\mathrm{Fe}$ and $\mathrm{H}_{2} \mathrm{~S}$, were not detected simultaneously in solution, suggesting efficient coprecipitation (Fig. 2b). The black color of the units with high $\mathrm{C} /$ soil ratios provided further evidence of the presence of Fe sulfides. A simultaneous release of dissolved $\mathrm{Fe}$ and $\mathrm{P}$ from soil was observed in the units with low $\mathrm{C} /$ soil ratio (Fig. 2d). A further increase in the $\mathrm{C} /$ soil ratio resulted in negligible concentration of Fe. The units with low (or no) $\mathrm{C}$ additions maintained their initial brownish color throughout the experiment (Fig. 3) and showed a low consumption of $\mathrm{SO}_{4}$ and no accumulation of $\mathrm{H}_{2} \mathrm{~S}$. Similar visible processes were observed in Incubation 2 until extra $\mathrm{C}$ was added and all units turned black.

The highest $\mathrm{pH}$ values were measured in the units with efficient $\mathrm{SO}_{4}$ reduction and high $\mathrm{H}_{2} \mathrm{~S}$ concentrations (Fig. $4 \mathrm{a}-\mathrm{c}$ ). Although the highest $\mathrm{P}$ release was found in the units with the highest $\mathrm{pH}$, the increase in $\mathrm{pH}$ was hardly the principal cause for $\mathrm{P}$ release (Fig. 4d), as described below.

\section{Effect of $\mathrm{C} /$ soil ratio on the release of $\mathrm{P}$}

The release of $\mathrm{P}$ correlated inversely with $\mathrm{SO}_{4}$ concentration (Fig. 5a), i.e., positively with $\mathrm{SO}_{4}$ consumption. This pattern can be explained by the collapse of the $\mathrm{P}$ binding ability of Fe by sulfides formed as a result of $\mathrm{SO}_{4}$ reduction. When the $\mathrm{C} /$ soil ratio exceeded 6 , the solution $\mathrm{P}$ concentration was a logarithmic function of soil concentration, but at lower $\mathrm{C} /$ soil ratios, the $\mathrm{P}$ concentrations were lower and also predicted by $\mathrm{C}$ concentration (Fig. 5 b). For example, the units with $1 \mathrm{~g}$ of soil, but no addition of $\mathrm{C}$ had an average $\mathrm{P}$ concentration of $1.25 \mathrm{mg} \mathrm{l}^{-1}(n=2)$, whereas the unit with the same soil amount but $12 \mathrm{mg} \mathrm{C}$ had a $\mathrm{P}$ concentration of $4.8 \mathrm{mg} \mathrm{l}^{-1}$. No corresponding change was found in exchangeable cations during the incubation (Table 2). 

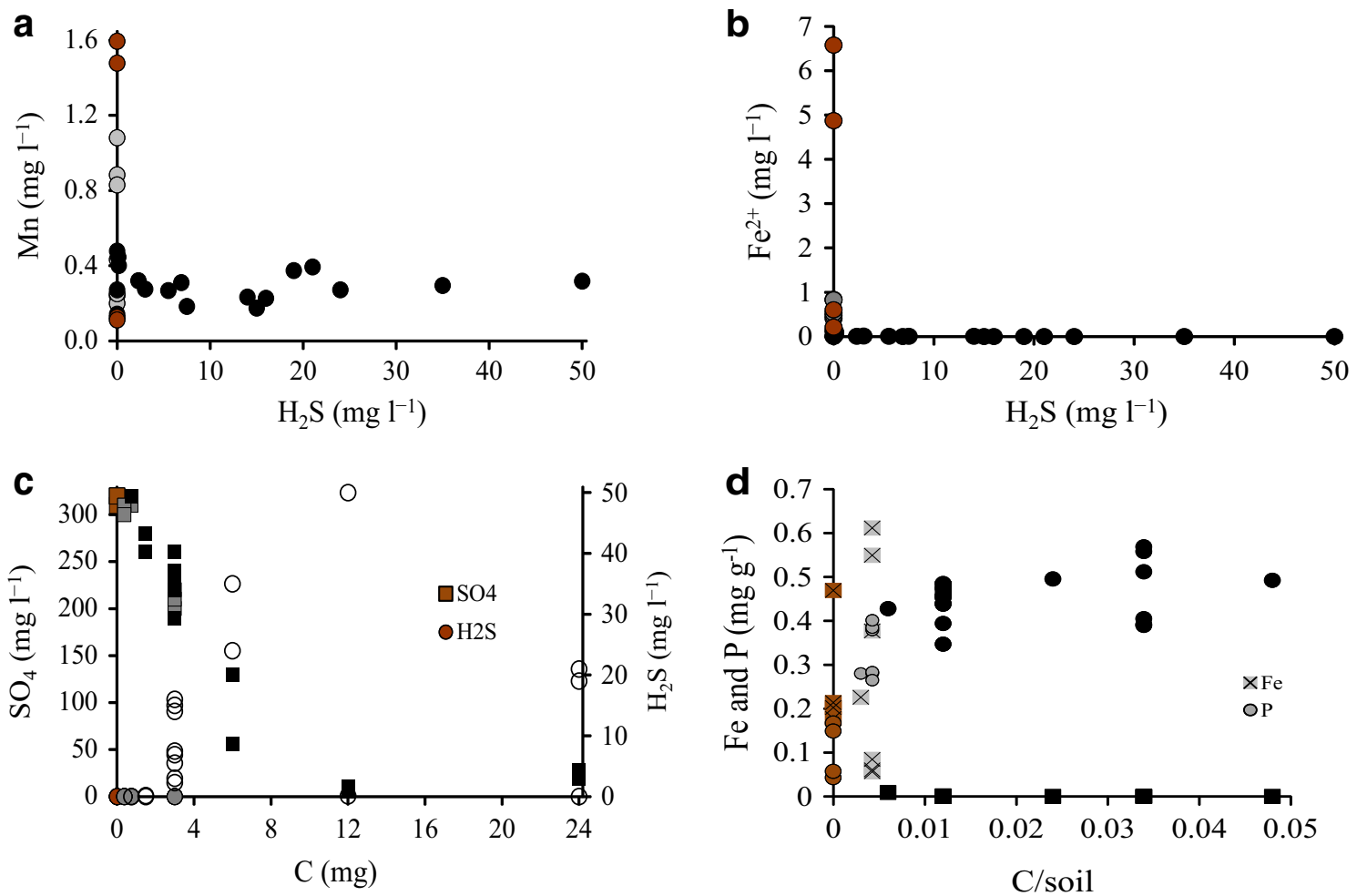

Fig. 2 Relationship between a the solution concentrations of manganese $(\mathrm{Mn})$ and hydrogen sulfide $\left(\mathrm{H}_{2} \mathrm{~S}\right)$; b reduced iron $\left(\mathrm{Fe}^{2+}\right)$ and $\mathrm{H}_{2} \mathrm{~S}$; c sulfate $\left(\mathrm{SO}_{4}\right)$ and $\mathrm{H}_{2} \mathrm{~S}$ and addition of carbon $(\mathrm{C})$; and $\mathbf{d ~ C}$ /soil ratio and iron (squares) and phosphorus (circles) released from soil to solution. Brown symbols represent the units without addition of $\mathrm{C}$, gray symbols the units with $\mathrm{C} /$ soil ratios $<6$, and black symbols the units with $\mathrm{C} / \mathrm{soil}$ ratios $\geq 6$

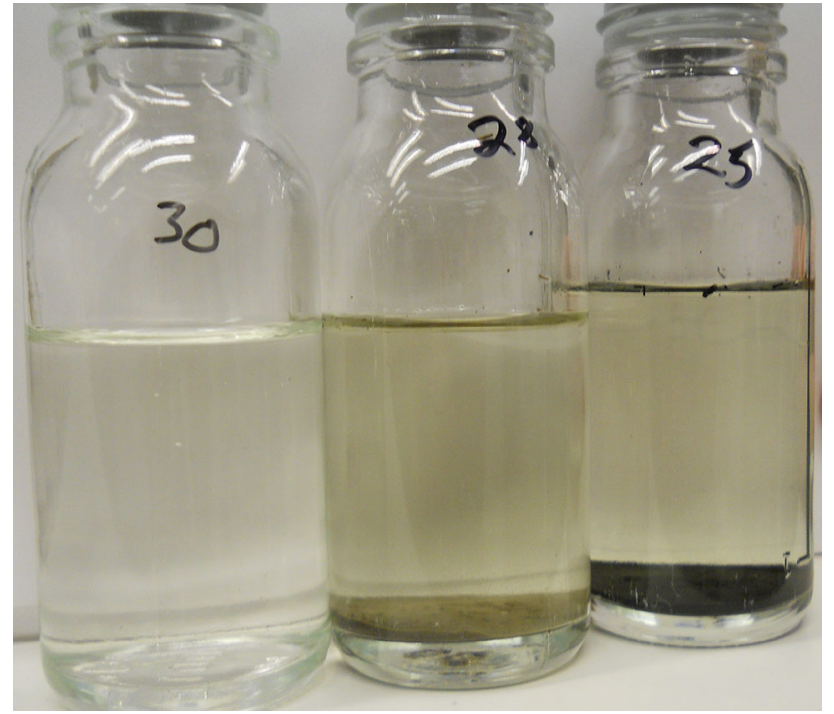

Fig. 3 The water of the Gulf of Finland without soil remained clear (left), and the units without addition of $\mathrm{C}$ (here $1.0 \mathrm{~g}$ soil) kept their brownish color (middle), but units with high C/soil ratio (here $24 \mathrm{mg}$ $\mathrm{C}$ and $0.71 \mathrm{~g}$ soil) turned black (right) in the anaerobic incubation. Photo by Jouni Lehtoranta
The regression model predicted the $\mathrm{P}$ release well, with the $E_{f}$ values ranging from 0.78 to 0.97 (Table 3; Fig. 6c). The theoretical maximum $\mathrm{P}$ releases, determined by letting soil approach 0 and $C$ infinity, were $0.70 \mathrm{mg} \mathrm{g}^{-1}$ in Incubation 1 and 0.47 in Incubation 2 (Table 3 showing the results for Incubation 2). Figure 6 depicts the effects of soil and $\mathrm{C}$ terms on the $\mathrm{P}$ release. The soil term appeared to overestimate desorption with low soil contents; the soil term indicated a $\mathrm{P}$ release of about $0.3 \mathrm{mg} \mathrm{g}^{-1}$ at low soil contents, which is a much higher value than that obtained by anion exchange resin $\left(0.12 \mathrm{mg} \mathrm{g}^{-1}\right)$ and repetitive extraction by nutrient med-

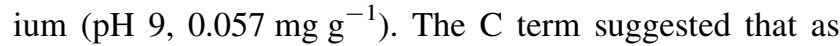
much as $97 \%$ of the $\mathrm{P}$ mobilized by $\mathrm{C}$ was already released at $C=6 \mathrm{mg}$.

In Incubation 2, the response of an extra $\mathrm{C}$ addition was tested after 141 and 196 days. The extra $C$ increased the $\mathrm{P}$ release only in the units with a low $\mathrm{C} /$ soil ratio. The extra $\mathrm{C}$ addition improved the fit of the model by increasing the dependence of $\mathrm{P}$ release from the amount of soil but not increasing the estimate for maximum $\mathrm{P}$ release (Fig. 6d). Therefore, the extra dose of organic C 

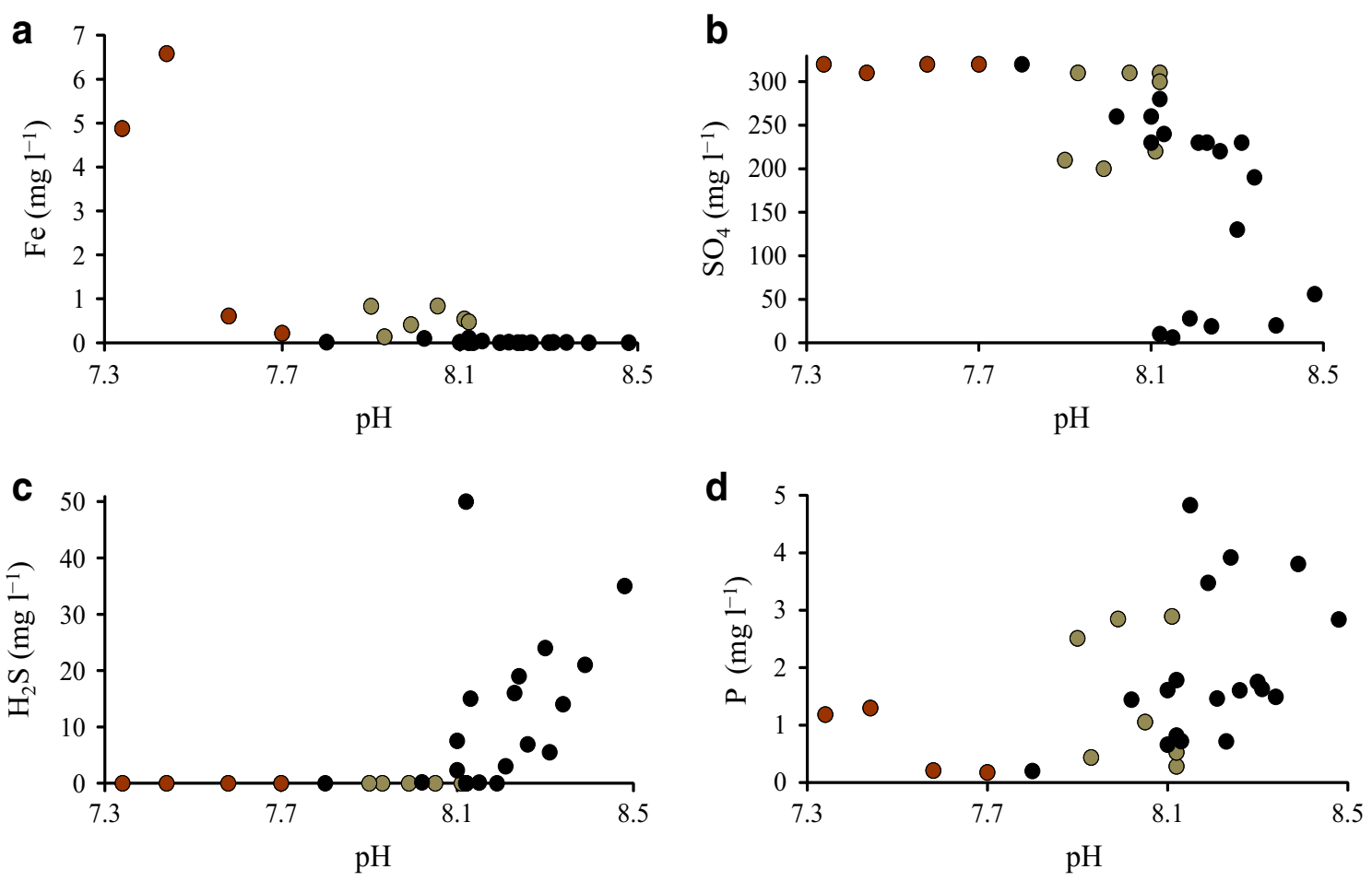

Fig. 4 Relationship between a pH and solution concentrations of iron $(\mathrm{Fe}) ; \mathbf{b} \mathrm{pH}$ and sulfate $\left(\mathrm{SO}_{4}\right)$; $\mathbf{c} \mathrm{pH}$ and hydrogen sulfide $\left(\mathrm{H}_{2} \mathrm{~S}\right)$; and $\mathbf{d} \mathrm{pH}$ and phosphorus (P). The brown symbols denote units without addition of organic carbon (C); the gray the units with $\mathrm{C} /$ soil ratios $<6$; and black symbols the units with $\mathrm{C} /$ soil ratios $\geq 6$
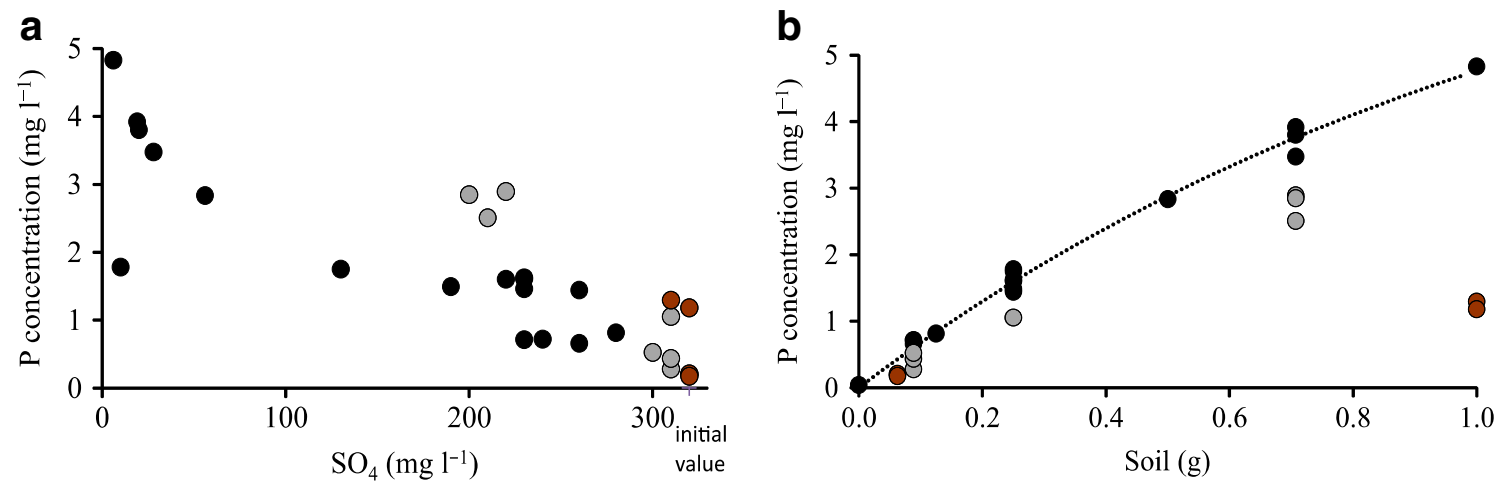

Fig. 5 Relationship between a the solution concentration of phosphorus $(\mathrm{P})$ and sulfate $\left(\mathrm{SO}_{4}\right)$. Low concentrations of $\mathrm{P}$ were generally associated with high concentrations of $\mathrm{SO}_{4}$. b The relationship between $\mathrm{P}$ concentration in solution and amount of soil (grams per $80 \mathrm{ml}$ of suspension). The brown symbols denote units without addition of $\mathrm{C}$, gray symbols the units with $\mathrm{C} /$ soil ratios $<6$, and black symbols the units with $\mathrm{C} /$ soil ratios $\geq 6$

Table 2 Variation (min-max) of exchangeable cations in test solution and suspensions (with and without addition of carbon) at the end of the incubation. $\mathrm{DL}=$ the lower detection limit

\begin{tabular}{lclllll}
\hline Experimental units & $n$ & $\mathrm{Al}\left(\mathrm{mg} \mathrm{l}^{-1}\right)$ & $\mathrm{Ca}\left(\mathrm{mg} \mathrm{l}^{-1}\right)$ & $\mathrm{K}\left(\mathrm{mg} \mathrm{l}^{-1}\right)$ & ${\mathrm{Mg}\left(\mathrm{mg} \mathrm{l}^{-1}\right)}^{\mathrm{Na}\left(\mathrm{mg} \mathrm{l}^{-1}\right)}$ \\
\hline Test solution & 3 & $<\mathrm{DL}$ & $70-71$ & 56 & $172-174$ & $1340-1360$ \\
No added carbon & 4 & $<\mathrm{DL}-0.06$ & $71-90$ & $46-56$ & $170-175$ & $1320-1350$ \\
Added carbon & 25 & $<\mathrm{DL}-0.11$ & $69-83$ & $39-55$ & $151-172$ & $1320-1500$ \\
\hline
\end{tabular}


Table 3 Regression equations for $\mathrm{P}$ release $(P)$ in Incubation 1. $P_{\max }$ is the maximum $\mathrm{P}$ release, $E_{\mathrm{f}}$ is the model efficiency index. Soil is given in grams and $C$ in milligrams

\begin{tabular}{llll}
\hline Duration & Phosphorus release $\left(\mathrm{mg} \mathrm{g}^{-1}\right)$, soil $\neq 0$ & $P_{\max }$ & $E_{\mathrm{f}}$ \\
\hline 738 & $P=0.27 \cdot \mathrm{e}^{-3.2 \cdot \text { soil }}+0.33 \cdot\left(1-\mathrm{e}^{-1.5 \cdot C}\right)$ & 0.61 & 0.90 \\
861 & $P=0.34 \cdot \mathrm{e}^{-2.1 \cdot \text { soil }}+0.35 \cdot\left(1-\mathrm{e}^{-0.6 \cdot C}\right)$ & 0.70 & 0.83 \\
\hline
\end{tabular}

a

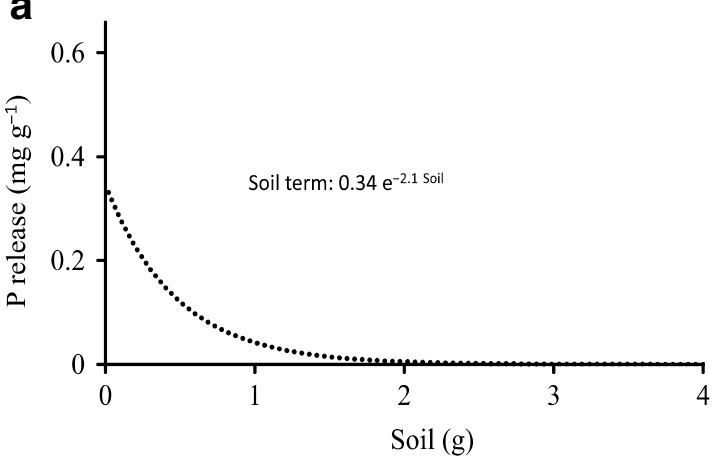

C

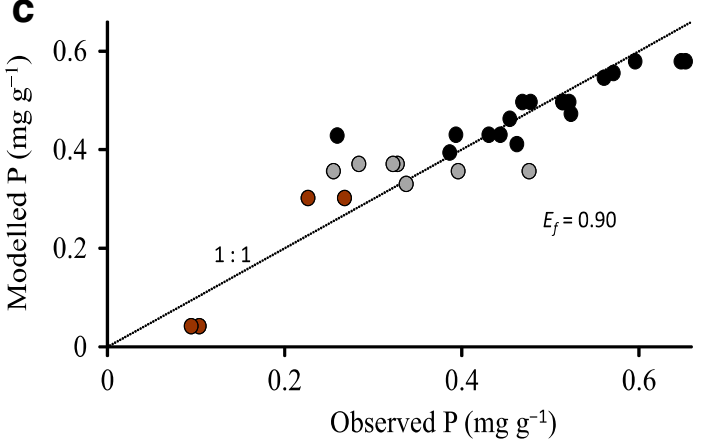

b
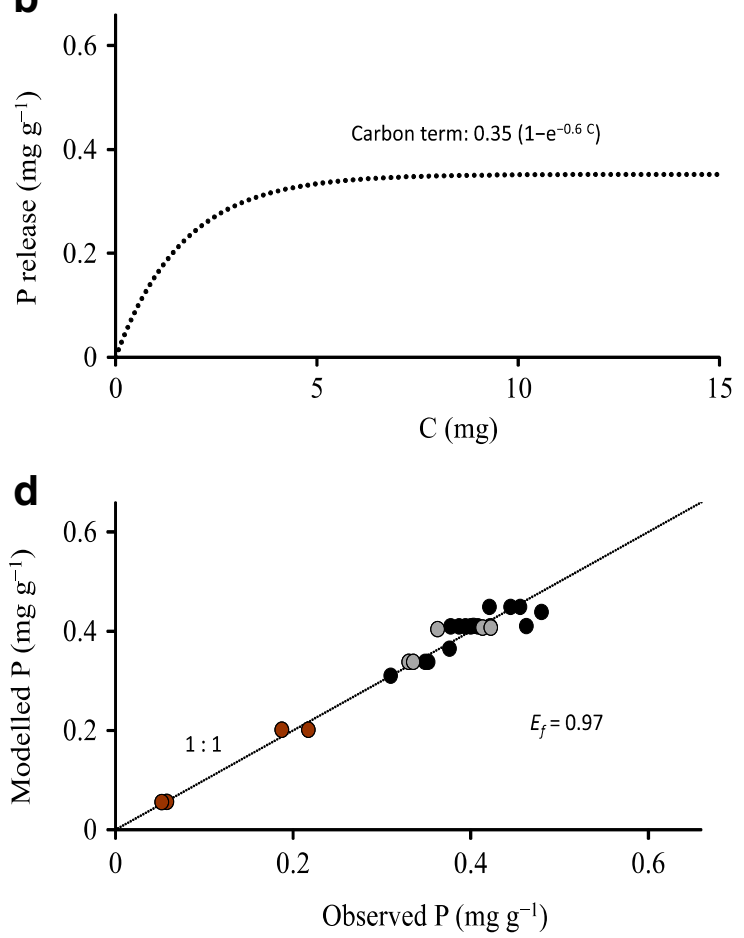

Fig. 6 a Effect of 'soil term' on the P release in Incubation 1 (861 days). b Effect of organic 'carbon term' on the P release. c Observed and modeled P releases in Incubation 1. d Observed and modeled P releases in Incubation 2 when the extra addition of organic C increased the C/soil ratio over 6 in all units. Brown symbols represent the units without addition of C; gray symbols the units with C/soil ratios $<6$; and black symbols the units with $\mathrm{C} /$ soil ratios $>6$. In $\mathbf{d}$, the colors denote the $\mathrm{C} /$ soil ratio of the starting point of the experiment without the extra addition and the actual $\mathrm{C} /$ soil ratio is $>6$ for all units. $E_{\mathrm{f}}$ is the model efficiency index

led to the release of $\mathrm{P}$ that could be modeled with the soil term alone. Sulfate itself seemed to have a small effect on $\mathrm{P}$ release: the high initial $\mathrm{SO}_{4}$ concentration (2400 $\mathrm{mg} \mathrm{l}^{-1}$ ) in Incubation 1 did not increase the $\mathrm{P}$ release from the soil in comparison with the lower initial value $310 \mathrm{mg}^{-1}$ of Incubation 2.

The average $\mathrm{P}$ release in units with $\mathrm{C} /$ soil $\geq 6$ was $0.48 \mathrm{mg} \mathrm{g}^{-1}$, more than twice the amount extracted with buffered dithionite (Fig. 7). The average $\mathrm{P}$ release was close to the sum of (1) $\mathrm{P}$ extracted by dithionite; (2) $\mathrm{P}$ extracted by water (soil/solution 1/100); and (3) the estimated amount of organic $\mathrm{P}$, the latter approximated from the $\mathrm{C}$ concentration of the soil. The maximum $\mathrm{P}$ release $\left(0.65 \mathrm{mg} \mathrm{g}^{-1}\right)$ was about three times the amount extracted by dithionite and $44 \%$ of the total $\mathrm{P}$ in the soil sample.

\section{DISCUSSION}

\section{Carbon and progressing microbial reduction}

In our bottle test, the redox-states, $\mathrm{pH}$, and the concentrations of $\mathrm{Mn}, \mathrm{Fe}, \mathrm{SO}_{4}$, and $\mathrm{H}_{2} \mathrm{~S}$ prevailing at the end of incubations were typical of those found in the sediments of brackish systems, such as the open and coastal Baltic Sea (see e.g., Lehtoranta and Heiskanen 2003; Reed et al. 2011). In sediments, most of the organic $C$ consists of compounds which are not readily available for mineralization. It is likely that the mineralization is controlled by the ability of the sediment to produce labile $\mathrm{C}$ compounds (e.g., by fermentation) rather than by the concentration of $\mathrm{C}$ itself. In our experiment, acetate was used to simulate a system that was able to produce labile $\mathrm{C}$ for microbial 


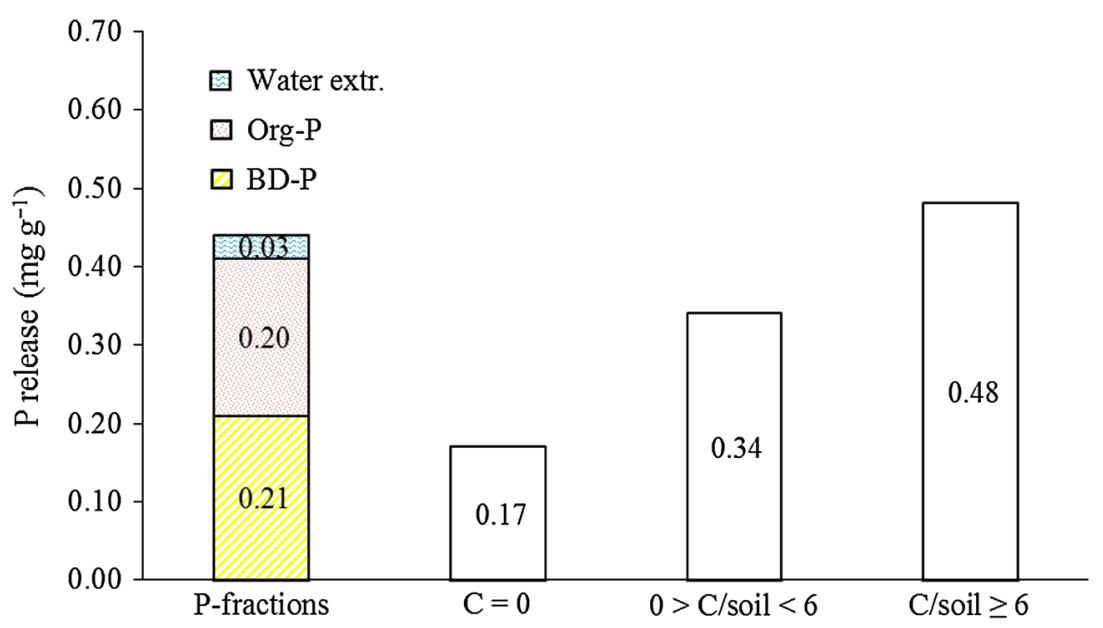

Fig. 7 Phosphorus fractions compared with average $\mathrm{P}$ released in different $\mathrm{C} /$ soil ratios $(C=0$ refers to no $\mathrm{C}$ addition $)$ showing the significance of the addition of $\mathrm{C}$ on release of $\mathrm{P}$. Phosphorus fractions consist of the $\mathrm{P}$ extracted with water and buffered dithionite (BD), and the estimated organic-P

mineralization using $\mathrm{Mn}, \mathrm{Fe}$, and $\mathrm{SO}_{4}$ as electron acceptors. By manipulating the supply of labile organic $\mathrm{C}$ to brackish soil suspensions, we initiated progressing redox evolution, analogous to that encountered by the eroded soil when it settles on anoxic sediments with different abilities to produce labile $\mathrm{C}$.

When no acetate was added, the organic $\mathrm{C}$ present in the soil was able to produce $\mathrm{Mn}$ and $\mathrm{Fe}$ in the solution, but $\mathrm{SO}_{4}$ remained at the initial level. Low additions of acetate maintained the accumulation of $\mathrm{Mn}$ and $\mathrm{Fe}$ and resulted in a minor decrease in $\mathrm{SO}_{4}$ (Fig. 2a-c). Thus, a low $\mathrm{C}$ level could trigger the microbial reductions of $\mathrm{Mn}$ and $\mathrm{Fe}$, but the system did not proceed into $\mathrm{SO}_{4}$ reduction with such an efficiency that it would have markedly decreased the level of $\mathrm{SO}_{4}$, even though Incubation 1 took more than 2 years. However, $\mathrm{SO}_{4}$ reduction was activated with higher additions of acetate. At moderate $\mathrm{C}$ levels, the concentration of $\mathrm{SO}_{4}$ decreased, but no $\mathrm{H}_{2} \mathrm{~S}$ was detected. The lack of $\mathrm{H}_{2} \mathrm{~S}$ was possibly due to coprecipitation of sulfides and $\mathrm{Fe}^{2+}$ in the solution (Chapelle et al. 2009), as suggested by the fact that the concentration of dissolved $\mathrm{Fe}$ was lower in these units.

A high $\mathrm{C}$ addition was required to exhaust the reserves of reactive $\mathrm{Mn}$ and $\mathrm{Fe}$ oxides in the soil, giving room for the dominance of $\mathrm{SO}_{4}$ reduction. When the $\mathrm{C} /$ soil ratio was at least 6 , soils in all units turned black, as a result of the transformation of $\mathrm{Fe}(\mathrm{III})$ oxides into black $\mathrm{Fe}$ sulfides. Furthermore, the concentration of dissolved $\mathrm{Fe}$ became nondetectable and $\mathrm{H}_{2} \mathrm{~S}$ accumulated into the water. The presence of $\mathrm{H}_{2} \mathrm{~S}$ indicates that even the abiotically reducible Fe oxides may have precipitated as Fe sulfides. The microbial and chemical processes in the experiment produce many simultaneous reactions with an opposite effect on $\mathrm{pH}$ (Soetaert et al. 2007), but in general, the $\mathrm{pH}$ was the lowest when dissolved $\mathrm{Fe}$ was present (low $\mathrm{C}$ additions) and the highest in units with presence of $\mathrm{H}_{2} \mathrm{~S}$ (high $\mathrm{C}$ additions, Fig. 4a-d).

\section{Organic $\mathbf{C}$ and $\mathbf{P}$ release}

Of the elements monitored, $\mathrm{P}$ was the only nonredoxdependent element that increased in concentration as a function of organic $\mathrm{C}$ (Table 2). However, after exceeding a threshold in $\mathrm{C} /$ soil ratio, further $\mathrm{C}$ additions caused lower additional $\mathrm{P}$ release, and the release could be modeled well with the amount of soil alone (Fig. 6d). The diminishing increase in P release from soil (Fig. 5b) could be due to, for example, $\mathrm{P}$ readsorption on $\mathrm{Fe}(\mathrm{II})$ hydroxides, $\mathrm{Al}$ oxides, and mineral surfaces (Patrick and Khalid 1974; Roden and Edmonds 1997; Gächter and Müller 2003).

When no $\mathrm{C}$ was added, the release of $\mathrm{P}$ was accompanied by the release of $\mathrm{Fe}$, with the molar $\mathrm{Fe} / \mathrm{P}$ ratio in solution ranging from 0.7 to 2.8 (calculated from data in Fig. 2d). This ratio indicates that microbial Fe reduction results in an accumulation of both $\mathrm{Fe}$ and $\mathrm{P}$, and presupposes that $\mathrm{Fe}$ has the capacity to bind most of the released $\mathrm{P}$, when oxic conditions are encountered (Blomqvist et al. 2004). Therefore, the eroded soil may carry enough Fe to capture the $\mathrm{P}$ released through this coupling of the $\mathrm{Fe}$ and $\mathrm{P}$ cycles in the brackish sedimentary systems, but our results indicate that this ability is maintained only in environments low in $\mathrm{C}$.

In the units with $\mathrm{C} /$ soil ratio $<6$, the molar $\mathrm{Fe} / \mathrm{P}$ ratio ranged from 0.02 to 0.50 and in the units with $\mathrm{C} /$ soil ratio $\geq 6$, the ratio was at maximum 0.1 and mostly zero. Thus, organic $\mathrm{C}$ had the ability to decouple the cycles of $\mathrm{Fe}$ and $\mathrm{P}$, through $\mathrm{SO}_{4}$ reduction, by deteriorating the capacity of $\mathrm{Fe}$ to retain $\mathrm{P}$. The pattern found follows the theory 
presented by Lehtoranta et al. (2009). Those authors hypothesized that anoxic oligotrophic brackish and marine sediments may be able to maintain the coupled Fe and $\mathrm{P}$ cycling, but if eutrophication proceeds, the ability of $\mathrm{Fe}$ to retain $\mathrm{P}$ is lost through the efficient reduction of $\mathrm{SO}_{4}$. Our results also endorse the previous study by Lehtoranta et al. (2008) which states that the ability of the surface sediment to retain $\mathrm{P}$ is related to the difference in the dominance of microbial $\mathrm{Fe}$ and $\mathrm{SO}_{4}$ reductions in the bottom areas of the Baltic Sea. However, we have only studied the behaviors of $\mathrm{Fe}, \mathrm{Mn}$, and $\mathrm{P}$ in a clayey soil, and our study gives little information about the fates of $\mathrm{Fe}$ and $\mathrm{P}$ bound, e.g., to humic matter in $\mathrm{SO}_{4}$-rich sedimentary systems. The forms of $\mathrm{C}, \mathrm{Fe}$, and $\mathrm{P}$ and their respective loadings from rivers to the subbasins of the Baltic Sea vary significantly from one region to another. The recipient sedimentary system may also respond differently to each load type, and the release of $\mathrm{P}$ may depend on the binding and the molar ratios of $\mathrm{C}$, $\mathrm{Fe}$, and $\mathrm{P}$ in the terrestrial material.

The $\mathrm{P}$ release in the units with high $\mathrm{C} /$ soil ratio exceeded the amount of $\mathrm{P}$ extracted by buffered dithionite that has earlier been used to estimate the mobile $\mathrm{P}$ in sulfidic sediments. The difference may be explained by the mineralization of organic $\mathrm{P}$ present in significant amounts in the test soil, and also by the duration of the anoxic period$15 \mathrm{~min}$ in the dithionite extraction as opposed to over two years in the incubations. During the incubation, microbes and sulfides may be able to liberate $\mathrm{P}$ also from the less readily accessible metal oxides (such as $\mathrm{P}$ in interiors of $\mathrm{Fe}$ oxides). In addition, the organic anions, such as acetate, may have competed with $\mathrm{PO}_{4}$ for adsorption sites (on organic anion competition, see, e.g., Froelich 1988), and the increased $\mathrm{pH}$ may have promoted $\mathrm{P}$ desorption via anion exchange with $\mathrm{OH}^{-}$and through the decreasing positive charge of oxide surfaces (Hingston et al. 1967; Caraco et al. 1989; Hawke et al. 1989; Hartikainen and YliHalla 1996). The addition of acetate was likely to elevate $\mathrm{pH}$ both directly due to its weak basicity $(\mathrm{pKb} \approx 9.3)$ and indirectly via $\mathrm{SO}_{4}$ and Fe reductions (Ben-Yaakov 1973; Lamers et al. 1998; Soetaert et al. 2007; Boudreau and Canfield 1993).

Our experimental approach may give insight into the mobility of soil-bound $\mathrm{P}$ under conditions where P-release is controlled by anaerobic microbial processes, serving as an additional method besides algal assays and chemical extractions. The long incubation may in part reflect realistic dynamics of microbial processes affecting the $\mathrm{P}$ release in brackish and marine sediments. In future tests, a shorter incubation time may be compensated by increasing the temperature. However, particulate organic $\mathrm{P}$ may behave differently compared to $\mathrm{P}$ bound to reactive $\mathrm{Fe}$ oxides. Studies from shallow coastal sediments have shown that the efficient reduction of $\mathrm{Fe}$ and release of $\mathrm{P}$ can be measured within weeks (Jensen et al. 1995; Kristiansen et al. 2002), but that the mineralization of organic $P$ may take years in anoxic sediments (Ahlgren et al. 2006). Therefore, a short incubation time may reveal better the release of $\mathrm{Fe}$ bound $\mathrm{P}$ than that of organic $\mathrm{P}$.

\section{CONCLUSIONS}

Under anoxic conditions, the release of $\mathrm{P}$ from soil was controlled by organic $\mathrm{C}$, suggesting that the mobility of $\mathrm{P}$ depends on the trophic status of the sedimentary system, i.e., mineralization potential created by labile organic $\mathrm{C}$. Our results propose that erosion control measures affecting the quantity and quality of fluxes of $\mathrm{Fe}$ and $\mathrm{P}$ may have a complicated outcome when it comes to eutrophication in the receiving water bodies. In an oligotrophic $\mathrm{SO}_{4}$-rich system, the soil matter settling at the bottom may carry enough $\mathrm{Fe}$ to prevent most of the $\mathrm{P}$ entering the surface waters. However, in a eutrophic $\mathrm{SO}_{4}$-rich system, the ability of Fe to capture $\mathrm{P}$ is lost by the Fe sulfide formation. This highlights that the efficiency of erosion control as a eutrophication abatement measure may to a large extent depend on the characteristics of the receiving aquatic system.

Acknowledgments This study was part of the MYTVAS project and TEAQUILA project in AKVA-programme (Decision number 263476) funded by the Academy of Finland. The authors are grateful to Visa Mäkelä for his help with the experiments and analyses.

Open Access This article is distributed under the terms of the Creative Commons Attribution License which permits any use, distribution, and reproduction in any medium, provided the original author(s) and the source are credited.

\section{REFERENCES}

Ahlgren, J., K. Reitzel, L. Tranvik, A. Gogoll, and E. Rydin. 2006. Degradation of organic phosphorus compounds in anoxic Baltic Sea sediments: A 31P nuclear magnetic resonance study. Limnology and Oceanography 51: 2341-2348.

Ben-Yaakov, S. 1973. pH buffering of pore water of recent anoxic marine sediments. Limnology and Oceanography 18: 86-94.

Blomqvist, S., A. Gunnars, and R. Elmgren. 2004. Why the limiting nutrient differs between temperate coastal seas and freshwater lakes: A matter of salt. Limnology and Oceanography 49: 2236-2241.

Boudreau, B.P., and D.E. Canfield. 1993. A comparison of closedand open-system models for porewater $\mathrm{pH}$ and calcite-saturation state. Geochimica et Cosmochimica Acta 57: 317-334.

Bowman, R. 1988. A rapid method to determine total phosphorus in soils. Soil Science Society of America Journal 52: 1301-1304.

Burgin, A.J., W.H. Yang, S.K. Hamilton, and W.L. Silver. 2011. Beyond carbon and nitrogen: how the microbial energy economy couples elemental cycles in diverse ecosystems. Frontiers in Ecology and the Environment 9: 44-52. 
Caraco, N.F., J.J. Cole, and G.E. Likens. 1989. Evidence for sulphatecontrolled phosphorus release from sediments of aquatic systems. Nature 341: 316-318.

Chapelle, F.H., P.M. Bradley, M.A. Thomas, and P.B. McMahon. 2009. Distinguishing iron-reducing from sulfate-reducing conditions. Ground Water 47: 300-305.

Conley, D.J., J. Carstensen, J. Aigars, P. Axe, E. Bonsdorff, T. Eremina, B.-M. Haahti, C. Humborg, et al. 2011. Hypoxia is increasing in the coastal zone of the Baltic Sea. Environmental Science and Technology 45: 6777-6783.

Daloğlu, I., K.H. Cho, and D. Scavia. 2012. Evaluating causes of trends in long-term dissolved reactive phosphorus loads to Lake Erie. Environmental Science and Technology 46: 10660-10666.

DePinto, J.V., T.C. Young, and S.C. Martin. 1981. Algal-available phosphorus in suspended sediments from lower Great Lakes Tributaries. Journal of Great Lakes Research 7: 311-325.

Ekholm, P., and M. Yli-Halla. 1992. Reversibly adsorbed phosphorus in agriculturally loaded rivers in southern Finland. Aqua Fennica 22: $35-41$

Ekholm, P., and K. Krogerus. 2003. Determining algal-available phosphorus of differing origin: routine phosphorus analyses versus algal assays. Hydrobiologia 492: 29-42.

Ekholm, P., and J. Lehtoranta. 2012. Does control of soil erosion inhibit aquatic eutrophication? Journal of Environmental Management 93: 140-146.

Ekholm, P., H. Rita, H. Pitkänen, R. Rantanen, J.M. Pekkarinen, and U. Münster. 2009. Algal-available phosphorus entering the Gulf of Finland as estimated by algal assays and chemical analyses. Journal of Environmental Quality 33: 2322-2333.

Froelich, P.N. 1988. Kinetic control of dissolved phosphate in natural rivers and estuaries: a primer on the phosphate buffer mechanism. Limnology and Oceanography 33: 649-668.

Gächter, R., and B. Müller. 2003. Why the phosphorus retention of lakes does not necessarily depend on the oxygen supply to their sediment surface. Limnology and Oceanography 48: 929-933.

Hartikainen, H., K. Rasa, and P.J.A. Withers. 2010. Phosphorus exchange properties of European soils and sediments derived from them. European Journal of Soil Science 61: 1033-1042.

Hartikainen, H., and M. Yli-Halla. 1996. Solubility of soil phosphorus as influenced by urea. Zeitschrift für Pflanzenernährung und Bodenkunde 159: 327-332.

Hawke, D., P.D. Carpenter, and K.A. Hunter. 1989. Competitive adsorption of phosphate on goethite in marine electrolytes. Environmental Science and Technology 23: 187-191.

Hingston, F.J., R.J. Atkinson, A.M. Posner, and J.P. Quirk. 1967. Specific adsorption of anions. Nature 215: 1459-1461.

Jansson, M., M. Berggren, H. Laudon, and A. Jonsson. 2012. Bioavailable phosphorus in humic headwater streams in boreal Sweden. Limnology and Oceanography 57: 1161-1170.

Jensen, H.S., P.B. Mortensen, F.O. Andersen, E. Rasmussen, and E. Jensen. 1995. Phosphorus cycling in a coastal marine sediment, Aarhus Bay, Denmark. Limnology and Oceanography 40: 908-917.

Kotai, J. 1972. Instructions for preparation of modified nutrient solution Z8 for algae. Oslo: NIVA publications B-11/69.

Kristiansen, K.D., E. Kristensen, and M.H. Jensen. 2002. The influence of water column hypoxia on the behaviour of manganese and iron in sandy coastal marine sediment. Estuarine, Coastal and Shelf Science 55: 645-654.

Lamers, L.P.M., H.B.M. Tomassen, and J.G.M. Roelofs. 1998. Sulfate-induced eutrophication and phytotoxicity in freshwater wetlands. Environmental Science and Technology 32: 199-205.

Lehtoranta, J., and A.-S. Heiskanen. 2003. Dissolved iron:phosphate ratio as an indicator of phosphate release to oxic water of the inner and outer coastal Baltic Sea. Hydrobiologia 492: 69-84.
Lehtoranta, J., and H. Pitkänen. 2003. Binding of phosphate in sediment accumulation areas of the eastern Gulf of Finland, Baltic Sea. Hydrobiologia 492: 55-67.

Lehtoranta, J., P. Ekholm, and H. Pitkänen. 2008. Eutrophicationdriven sediment microbial processes can explain the regional variation in phosphorus concentrations between Baltic Sea subbasins. Journal of Marine Systems 74: 495-504.

Lehtoranta, J., P. Ekholm, and H. Pitkänen. 2009. Coastal eutrophication thresholds: A matter of sediment microbial processes. AMBIO 38: 303-308.

Nash, J., and J.V. Sutcliffe. 1970. River flow forecasting through conceptual models part I-A discussion of principles. Journal of Hydrology 10: 282-290.

Patrick, W.H.J., and R.A. Khalid. 1974. Phosphate release and sorption by soils and sediments: effect of aerobic and anaerobic conditions. Science 186: 53-55.

Puustinen, M., S. Tattari, J. Koskiaho, and J. Linjama. 2007. Influence of seasonal and annual hydrological variations on erosion and phosphorus transport from arable areas in Finland. Soil \& Tillage Research 93: 44-55.

Puustinen, M., E. Turtola, M. Kukkonen, J. Koskiaho, J. Linjama, R. Niinioja, and S. Tattari. 2010. VIHMA-A tool for allocation of measures to control erosion and nutrient loading from Finnish agricultural catchments. Agriculture, Ecosystems \& Environment 138: 306-317.

Reed, D.C., C.P. Slomp, and B.G. Gustafsson. 2011. Sedimentary phosphorus dynamics and the evolution of bottom-water hypoxia: A coupled benthic-pelagic model of a coastal system. Limnology and Oceanograohy 56: 1075-1092.

Rekolainen, S., P. Ekholm, L. Heathwaite, J. Lehtoranta, and R. Uusitalo. 2006. Off-site effects of erosion: Eutrophication as an example. In Soil erosion in Europe, ed. J. Boardman, and J. Poesen, 775-789. Chichester: Wiley.

Roden, E.E., and J.W. Edmonds. 1997. Phosphate mobilization in ironrich anaerobic sediments: Microbial Fe(III) oxide reduction versus iron-sulfide formation. Archiv für Hydrobiologie 139: 347-378.

Schwertmann, U. 1964. Differenzierung der Eisenoxide des Bodens durch photochemische Extraktion mil saurer Ammoniumoxalat-Losung. Zeitschrift für Pflanzenernährung und Bodenkunde 105: 194-202.

Sharpley, A.N. 1993. An innovative approach to estimate bioavailable phosphorus in agricultural runoff using iron oxide impregnated paper. Journal of Environmental Quality 22: 597-601.

Sibbesen, E. 1977. An investigation of the anion exchange resin method for soil phosphate extraction. Plant and Soil 46: 665-669.

Soetaert, K., A.F. Hofmann, J.J. Middelburg, F.J.R. Meysman, and J. Greenwood. 2007. The effect of biogeochemical processes on pH. Marine Chemistry 105: 30-51.

Tilman, D., K.G. Cassman, P.A. Matson, R. Naylor, and S. Polasky. 2002. Agricultural sustainability and intensive production practices. Nature 418: 671-677.

Ulén, B., H. Aronsson, M. Bechmann, T. Krogstad, L. Øygarden, and M. Stenberg. 2010. Soil tillage methods to control phosphorus loss and potential side-effects: A Scandinavian review. Soil Use and Management 26: 94-107.

UNESCO. 1981. The practical salinity scale 1978 and the international equation of state of seawater. Technical Paper Marine Sciences 36 .

Uusitalo, R., and P. Ekholm. 2003. Phosphorus in runoff assessed by anion exchange resin extraction and an algal assay. Journal of Environmental Quality 32: 633-641.

Uusitalo, R., and E. Turtola. 2003. Determination of redox-sensitive phosphorus in field runoff without sediment preconcentration. Journal of Environmental Quality 32: 70-77.

Uusitalo, R., E. Turtola, and R. Lemola. 2007. Phosphorus losses from a subdrained clayey soil as affected by cultivation practices. Agricultural and Food Science 16: 352-365. 
Vähätalo, A.V., H. Aarnos, and S. Mäntyniemi. 2010. Biodegradability continuum and biodegradation kinetics of natural organic matter described by the beta distribution. Biogeochemistry. doi:10.1007/s10533-010-9419-4.

Vuorinen, J., and O. Mäkitie. 1955. The method of soil testing in use in Finland. Agrogeological Publications 63: 1-44.

Yli-Halla, M., and H. Hartikainen. 1996. Release of soil phosphorus during runoff as affected by ionic strength and temperature. Agricultural and Food Science in Finland 5: 193-202.

Yli-Halla, M., H. Hartikainen, P. Ekholm, E. Turtola, M. Puustinen, and K. Kallio. 1995. Assessment of soluble phosphorus load in surface runoff by soil analyses. Agriculture, Ecosystems \& Environment 56: 53-62.

\section{AUTHOR BIOGRAPHIES}

Jouni Lehtoranta $(\bowtie)$ is a senior researcher specializing in biogeochemistry in sediments at the Finnish Environment Institute.

Address: Finnish Environment Institute (SYKE), P.O. Box 140, 00251 Helsinki, Finland.

e-mail: jouni.lehtoranta@environment.fi

Petri Ekholm is a limnologist at the Finnish Environment Institute with research focus on diffuse pollution.

Address: Finnish Environment Institute (SYKE), P.O. Box 140, 00251 Helsinki, Finland.

e-mail: petri.ekholm@environment.fi
Stella Wahlström is a graduate from Aalto University. She wrote her Master's thesis on phosphorus release from soil due to anaerobic processes.

Address: Aalto University, P.O. Box 11000, 00076 Aalto, Espoo, Finland.

e-mail: stella.wahlstrom@gmail.com

Petra Tallberg is a limnologist at the University of Helsinki. She is working on biogeochemical silicon cycling.

Address: Department of Environmental Sciences, University of Helsinki, P.O. Box 65, 00014 University of Helsinki, Finland.

e-mail: petra.tallberg@helsinki.fi

Risto Uusitalo is a soil scientist at Natural Resources Institute Finland. His research deals with $\mathrm{P}$ fertilization, soil $\mathrm{P}$ characterization, and $\mathrm{P}$ losses and their mitigation.

Address: Natural Resources Institute Finland, 31600 Jokioinen, Finland. e-mail: risto.uusitalo@mtt.fi 